\title{
LANDFILL LEACHATE TREATMENT BY BATCH SUPERCRITICAL WATER OXIDATION
}

\section{TRATAMIENTO DE LIXIVIADOS DE RELLENO SANITARIO POR MEDIO DE OXIDACIÓN EN AGUA SUPERCRÍTICA}

\author{
Victor Fernando Marulanda Cardona* \\ Paola Andrea Marulanda Buitrago** \\ Didier Haid Alvarado Acosta** \\ Fecha de recepción: 22 de septiembre de 2016 \\ Fecha de revisión: 8 de marzo de 2017 \\ Fecha de aprobación: 12 de mayo de 2017
}

Cómo citar: V. F. Marulanda Cardona, P. A. Marulanda Buitrago y D. H. Alvarado Acosta, "Landfill Leachate Treatment by batch supercritical water oxidation," Ciencia e Ingeniería Neogranadina, vol. 27, no. 2, pp. 5-26, 2017.

DOI: http://dx.doi.org/10.18359/rcin.2305

\section{ABSTRACT}

Landfill leachate treatment has been the focus of a great deal of research through different physicochemical and biological methods. However, no single method successfully addresses the required destruction efficiencies regarding organic matter and nitrogen, which is why the treatment is done employing combined technologies. Supercritical water oxidation (SCWO), a process that takes place at temperatures and pressures above the critical point of water and in the presence of a source of oxygen, has been successfully applied to the treatment of different types of wastewaters in an efficient way. Therefore, this paper presents an experimental study of the supercritical water oxidation of landfill leachate in a batch reactor in the temperature range $400-500^{\circ} \mathrm{C}$, reaction times from 15 to 30 minutes and oxygen excess (OE) from $100 \%$ to $300 \%$. Total organic carbon (TOC) and Total nitrogen (TN) destruction efficiencies

* Chemical Engineer, Ph.D. in Engineering. La Salle University, Titular Professor. Bogotá, Colombia. E-mail: vfmarulanda@lasalle.edu.co. ORCID: http://orcid.org/0000-0001-8038-2536

** Environmental and Sanitary Engineer. Bogota, Colombia. E-mail: pmarulanda66@unisalle.edu.co. ORCID: http://orcid.org/0000-0001-9168-5591

*** Environmental and Sanitary Engineer, Student of MSc. Hydrogeology, University of Strathclyde, Glasgow, United Kindom. E-mail: didier.alvarado-acosta.2016@uni.strath.ac.uk. ORCID: http://orcid.org/0000-0002-7092-0721 
were measured in the reactor effluent samples and the combined effect of the studied factors was analyzed by means of the Analysis of Variance (ANOVA). Optimal operation conditions for TOC destruction were $400^{\circ} \mathrm{C}, 30 \mathrm{~min}$ and $100 \% \mathrm{OE}$, being $500^{\circ} \mathrm{C}, 30 \mathrm{~min}$ and $100 \% \mathrm{OE}$ for TN destruction. Contrary to what has been reported in similar studies, the results suggest that it is possible to accomplish the simultaneous TOC and TN destruction in leachate wastewater by SCWO treatment at $400^{\circ} \mathrm{C}, 100 \% \mathrm{OE}$ and residence times longer than $30 \mathrm{~min}$ and without using a catalyst, either in batch or in a continuous process, as long as both the oxidant and the wastewater are mixed and heated together at the reaction temperature.

Keywords: Landfill leachate, SCWO, TOC destruction, Total Nitrogen destruction.

\section{RESUMEN}

El tratamiento de lixiviados por medio de diferentes procesos fisicoquímicos y biológicos ha sido ampliamente estudiado. Sin embargo, ningún proceso logra las eficiencias de destrucción requeridas en cuanto a materia orgánica y nitrógeno, razón por la cual el tratamiento se realiza por medio de tecnologías combinadas. La oxidación en agua supercrítica o SCWO, proceso que se lleva a cabo a temperaturas y presiones superiores a las del punto crítico del agua en presencia de una fuente de oxígeno, se ha aplicado exitosamente al tratamiento de distintos tipos de aguas residuales de forma eficiente. Por lo tanto, este trabajo presenta un estudio experimental de la oxidación en agua supercrítica de lixiviados de relleno sanitario en un reactor batch, en el rango de temperatura de $400-500^{\circ} \mathrm{C}$, tiempos de reacción de 15 a $30 \mathrm{mi}-$ nutos y excesos de oxígeno (OE) de $100 \%$ a $300 \%$. Se midieron las eficiencias de destrucción de carbono orgánico total (COT) y nitrógeno total (NT), y se determinó el efecto combinado de los factores estudiados por medio del Análisis de Varianza (ANOVA). Las condiciones de operación óptimas para la destrucción de COT fueron $400^{\circ} \mathrm{C}, 30$ min y $100 \% \mathrm{OE}$, y $500^{\circ} \mathrm{C}, 30$ min y $100 \%$ OE para el NT. A diferencia de lo reportado en estudios similares, los resultados sugieren que es posible llevar a cabo la destrucción simultánea del COT y el NT en los lixiviados por medio de SCWO a $400^{\circ} \mathrm{C}, 100 \%$ OE y tiempos de residencia de más de 30 min sin usar un catalizador, ya sea en un proceso batch o continuo, siempre y cuando tanto el oxidante como el agua residual se mezclen y se calienten juntos a la temperatura de reacción.

Palabras clave: Lixiviados, SCWO, destrucción de COT, destrucción de nitrógeno total.

\section{INTRODUCTION}

Municipal solid waste management dumped inappropriately in nonengineered landfill sites generates highly contaminated wastewater called leachate [1]. Landfill leachate results from the degradation of the waste organic fraction in combination with percolation of rainwater through solid waste piles [2]. Due to different biochemical processes that take place as a result of the stabilization of the organic matter in the waste pile, 
landfill leachate is heavily contaminated with organic matter and ammonia nitrogen from the ammonification of organic nitrogen, heavy metals and other toxic and priority pollutants. Environmental impacts caused by wastewater of such characteristics, associated with the depletion of oxygen and eutrophication in receiving surface and ground waters, are well documented. Management of landfills could result in several environmental impacts, for example, the percolation of leachates into the groundwater [3]. Therefore, an efficient wastewater treatment for landfill leachate must abate not only the organic matter load but also nitrogen and heavy metals, irrespective of the variations in volumetric flow and composition. According to the International Solid Waste Association, a landfill is the "engineered deposit of waste onto or into land in such a way that pollution or harm to the environment is prevented" [4].

In this aspect, landfill leachate treatment continues to be an area of intense research by different physicochemical, biological and emerging methods. However, no single technology claims to handle this heavily polluted residue in an efficient way or compliance with the most stringent regulations without operational constrains that limit in one way or another its practical application. Several authors have extensively reviewed the advantages and drawbacks of conventional as well as emerging leachate treatment process using leachate transfer, biodegradation, physical and chemical methods and membrane processes [2], [5]. It is evident from these thorough reviews that the application of the conventional physicochemical and biological treatment technologies to leachate treatment is hindered not only by insufficient che- mical oxygen demand (COD) and nitrogen removal efficiencies, but also for operational constraints such as the age of the leachate in the case of anaerobic biological processes, excessive sludge production, ammonia inhibition and energy expenditure in aerobic biological processes, and sludge production and chemicals products consumption in the case of physicochemical processes. With only a few exceptions, COD removal efficiencies varied from poor to moderate, and ammonia nitrogen, recalcitrant compound and considered the rate-limiting step in the total mineralization of organic matter [6], [7], is scarcely addressed. For example, reverse osmosis technology has complemented or replaced conventional landfill leachate treatment. The large volume of concentrate needs to be properly treated. Labiadh et al. [8] used anodic oxidation combined with electro-Fenton processes to treat the concentrate and found, under the most favorable electro-Fenton conditions, removal rates of $60 \%$ and $22 \%$ for COD and TN, respectively. Xu et al. [9] also used a Fenton process for leachate treatment membrane concentrates and reached $68.9 \%$ TOC reduction. No reference was made to $\mathrm{TN}$ or ammonia nitrogen reduction in this study.

Also, and in spite of all of the experimental work reported, it is not possible to make general recommendations regarding the operational conditions and expected performances of conventional processes. For example, hydraulic retention times (HRT) for activated sludge processes, sequencing batch reactors and digesters, vary from a few hours to several weeks for treatment of leachate with similar COD [5]. More recently, membranes, especially reverse osmosis (RO), have 
emerged as an alternative to physicochemical and biological processes. Issues related to fast membrane fouling and the necessary chemical cleaning procedure, which shortens lifetime and decreases the productivity of the membrane, remain as serious drawbacks. A physicochemical process as a pretreatment step before RO could improve the operation while reducing the frequency of membrane cleaning and consumption of chemicals [10].

A great deal of potential impact can be associated with ammonia nitrogen and heavy metals in the environment. Therefore, an allaround leachate treatment process should be assessed not only from the organic matter removal, measured as COD, BOD or TOC reduction, but also ammonia nitrogen and heavy metals abatement. At the same time, it must be done through a single process system, not easily affected by variations in waste chemical composition, nor requiring any additional pretreatment operations, such as $\mathrm{pH}$ conditioning or ammonia stripping. Lastly, it should not produce an additional byproduct to be further dealt with, such as biological sludge and gases, as occurs in biological treatment processes [2], [5]. All of these criteria could be satisfied by a process known as supercritical water oxidation or SCWO. This is an advanced oxidation process that takes advantage of the fascinating properties of supercritical water as a reaction medium at conditions of temperature and pressure higher than the critical point of water $\left(374{ }^{\circ} \mathrm{C}\right.$ and $\left.22.1 \mathrm{MPa}\right)$ [11]. At these conditions, and as a result of the loss of hydrogen bonding, water is completely miscible with organic compounds and oxygen. Therefore, it is possible to carry out rapid oxidation reactions in a single-phase media at very high temperature without mass transfer limitations. Hydrogen peroxide solutions, pure oxygen and compressed and enriched air are used as oxidants in SCWO. Although the required extreme pressure and temperature conditions could impose a high-energy expenditure, SCWO has the potential to be considered a clean energy process [12]. The heat released by the oxidation reaction could be converted to heat and shaft work, assuring a self-sustained reaction, as well as generate excess shaft power to drive both the high-pressure pump and the air compressor, as shown by García-Rodríguez [13]. Several studies have performed supercritical processes economic assessments through process simulation [14]. While these processes require a higher capital investment due to the cost of high-pressure equipment, in the long run, are more profitable due to the possibility of recovering energy from the reactor outlet, cheaper feedstocks and the reduced number of process operations [15], [16].

SCWO has been successfully applied to the treatment of different kinds of persistent and anthropogenic wastes characterized by a high COD and heavy metals concentration. These wastes cannot be efficiently or economically handled by conventional waste treatment technologies such as incineration. Cui et al. [17] reported a COD removal rate up to $92 \%$ on oily sludge wastes in less than 10 minutes of reaction time (RT) at $450{ }^{\circ} \mathrm{C}$, $25 \mathrm{MPa}$, and $427 \%$ oxygen excess. Akg et al. [18] studied the treatment of textile wastewater by SCWO and reported a decrease in the chemical oxygen demand up to $98.52 \%$ in short reaction times, between 4-12 s and temperatures between $400-600^{\circ} \mathrm{C}$ at $25 \mathrm{MPa}$. The difference in reaction times was attribu- 
ted to the reaction system, being shorter in the continuous one. Du et al. [19] reported a continuous flow supercritical water oxidation process to treat high strength COD coking wastewater, which also contained high concentrations of $\mathrm{NH}_{3}-\mathrm{N}$, phenol, and inorganic salts. COD destruction close to $99 \%$ at temperature $650^{\circ} \mathrm{C}$, a pressure of $25 \mathrm{MPa}$, reaction time $24 \mathrm{~s}$ and $300 \%$ excess oxygen was achieved. Veriansyah et al. [20] reported the SCWO of wastewater from liquid crystal display (LCD) manufacturing process, which contains a wide variety of organic pollutants and chromium. A COD conversion greater than $99.99 \%$ was obtained at $615^{\circ} \mathrm{C}, 25$ $\mathrm{MPa}, 998 \%$ oxygen excess and $10 \mathrm{~s}$ residence time and more than $97 \%$ chromium in the wastewater was recovered as chromium oxide. Marulanda and Bolaños [15] studied the SCWO of a heavily PCB-contaminated transformer oil in a continuos process. It was achieved a $99.6 \%$ organic matter conversion and destruction of PCBs under the analytical technique detection limit at $539^{\circ} \mathrm{C}, 24.1$ $\mathrm{MPa}$, and $350 \%$ oxygen excess. Despite its advantages over conventional end-of-pipe technologies, SCWO has met difficulties at a full scale commercial activity, as reviewed by Marrone [21]. Corrosion, plugging, materials durability and out-of-spec feed are the main reasons behind the shutdown of several full-scale plants. New companies continue to enter the field.

Leachate treatment by supercritical water oxidation has been recently reported by several groups using either continuous or batch processes. Gong and Duan [22] studied a landfill leachate treatment process using a continuous system with a transpiring-wall reactor (TWR). In this study, diluted leachate and excess oxidant were fed to the reaction system. COD removal efficiencies were higher than $97 \%$ at $430 \mathrm{C}$ and $30 \mathrm{MPa}$. Alternatively, Wang et al. [23] studied the supercritical water oxidation of landfill leachate with a special focus on ammonia in a batch reactor, at temperatures $380-500^{\circ} \mathrm{C}$, reaction time of 50-300 s, oxygen excess (OE) from 100 to $450 \%$ and pressure of $25 \mathrm{MPa}$, with and without $\mathrm{MnO}_{2}$ as a catalyst. Through a response surface analysis, it was shown that $\mathrm{NH}_{3}$ and COD conversions were low at temperatures near $400{ }^{\circ} \mathrm{C}$ and short reaction times. Zou et al. [24] studied the co-destruction of organic pollutants in leachates and dioxins in fly ash from leachates incineration using supercritical water oxidation in a batch reactor at different temperatures from $400-500^{\circ} \mathrm{C}$, Oxygen excess from stoichiometric to $300 \%$ and residence times of 1 and 2 min. Similar conclusions to those reported by Wang et al. [23], with a maximum COD conversion of $99.2 \%$ at $500^{\circ} \mathrm{C}, 300 \% \mathrm{OE}$ and $2 \mathrm{~min}$ and $\mathrm{PCDD} / \mathrm{F}$ degradation efficiency $>90 \%$, were reported. Nitrogen was not addressed in this study.

A leachate treatment process based on SCWO technology could improve on existing physicochemical and biodegradation processes in aspects such as the organic matter and ammonia-nitrogen conversion, as well as the absence of sludge that needs further treatment [21]. In order to assess the feasibility of the scale-up of the process to an industrial level, additional experiments should be conducted to elucidate the effect of the different variables in the leachate treatment by SCWO, in such a way that the lab scale experiments give insights on a possible pilot plant operation. Accordingly, the batch SCWO of landfill leachate with hydrogen peroxide is 
reported in this work. Process performance is assessed employing a factorial experimental design. Individual factors and its interactions in Total Organic Carbon (TOC) and Total Nitrogen (TN) destruction efficiencies were analyzed.

\section{MATERIALS AND METHODS}

\subsection{Experimental apparatus}

SCWO experiments were carried out in a batch reactor made of $1 / 22^{\prime \prime}(1.27 \mathrm{~cm})$ OD Swagelok tubing and fittings, $0.17 \mathrm{~cm}$ wall thickness, and $25 \mathrm{~cm}$ length for a total reaction volume of $16.98 \mathrm{~cm}^{3}$. The reactor withstands a maximum pressure of $35 \mathrm{MPa}$ at $500{ }^{\circ} \mathrm{C}$. A PID temperature controller oven $\left( \pm 2^{\circ} \mathrm{C}\right)$ was used to carry out the experiments.

\subsection{Material and analytical methods}

Landfill leachate was collected from a sanitary landfill located in the city of Villavicencio in Colombia, in a WWTP affluent sampling port. $\mathrm{HCl}$ to $\mathrm{pH} 2$ was added to preserve the sample and was protected from sunlight and atmospheric oxygen. The sample was kept in a freezer. Hydrogen peroxide $\left(\mathrm{H}_{2} \mathrm{O}_{2}\right)$ $30 \mathrm{wt} \%$ solution (Merck) was used as the oxidant. Hydrogen peroxide decomposition in supercritical water produces $\mathrm{OH}$ radical, which is extremely reactive. However, it is also very unstable and rapidly decomposes to oxygen [25], [26].

Total organic carbon (TOC) and total nitrogen (TN) were measured before and after SCWO treatment following adapted methods corresponding to standardized methods 5310D for TOC in a DR 3800 Hach Spectrophotometer, and TNb 220 for organically and inorganically bound nitrogen in a Macherey-Nagel nano color Vario 4 Spectrophotometer. Instruments blank were prepared with distilled and deionized water after adding the contents of the ampuls or decomposition reagents required for each method, digested in thermo reactor and set to $0.0 \mathrm{mg} / \mathrm{L}$ in both cases. TOC is considered more convenient than $B O D$ or $C O D$ due to the presence of organic carbon that does not respond to either of these methods. Total Nitrogen is the sum of nitrate-nitrogen $\left(\mathrm{NO}_{3}-\mathrm{N}\right)$, nitrite-nitrogen $\left(\mathrm{NO}_{2}-\mathrm{N}\right)$, ammonia-nitrogen $\left(\mathrm{NH}_{3}-\mathrm{N}\right)$ and organically bonded nitrogen. Several authors have shown that nitrate and nitrite nitrogen can be formed in SCWO. Therefore, TN is more representative of nitrogen fate in SCW than Total Kjeldahl Nitrogen (TKN), which has into account only ammonia and organic nitrogen.

Total organic carbon and total nitrogen destruction efficiencies were defined according to Equations (1) and (2):

$$
\begin{gathered}
X_{T O C}=\frac{T O C_{i}-T O C_{f}}{T O C_{i}} \\
X_{T N}=\frac{T N_{i}-T N_{f}}{T N_{i}}
\end{gathered}
$$

Where $\mathrm{TOC}_{\mathrm{i}}$ and $\mathrm{TN}_{\mathrm{i}}$ are the initial concentration of total organic carbon and total nitrogen in the leachate after the dilution with $30 \mathrm{wt} \%$ hydrogen peroxide solution and $\mathrm{TOC}_{\mathrm{f}}$ 
and $\mathrm{TN}_{f}$ are the corresponding concentrations in the reactor effluent.

\subsection{Experimental procedure}

In a typical batch run, a volume of leachate sample is added to the required volume of 30 $w t \%$ hydrogen peroxide solutions to provide the oxygen according to the desired oxygen excess for a specific run. Then an amount of reaction mixture is added to one end of the reactor utilizing volumetric pipettes and sealed with screw caps. The reactor is placed in an electrical insulated clamp-type oven previously heated to the desired reaction temperature, as shown in Fig. 1 and the batch reaction time is set to zero. Once the reaction time is complete, the oven is open and the reactor removed and rapidly quenched in a water bath to stop the reaction.

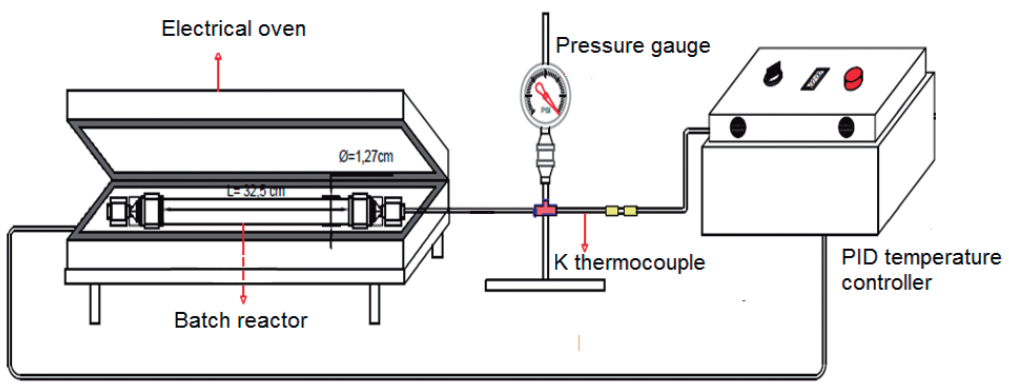

Fig. 1. Batch reaction system set-up

Source: The authors.

TOC, TN, and $\mathrm{pH}$ were measured in the raw landfill leachate sample as $8700 \mathrm{mg} / \mathrm{L}, 2800$ $\mathrm{mg} / \mathrm{L}$ and 6.3 , respectively. In a typical experimental run, a given amount of undiluted leachate was mixed with a volume of $30 \mathrm{wt} \%$ hydrogen peroxide solution, according to the amount of oxidant excess and having into account the reactions for hydrogen peroxide decomposition in SCW [26] and TOC oxidation (Ecuations 3 and 4):

$$
\begin{gathered}
\mathrm{H}_{2} \mathrm{O}_{2} \rightarrow \mathrm{H}_{2} \mathrm{O}+1 / 2 \mathrm{O}_{2} \\
\mathrm{C}+\mathrm{O}_{2} \rightarrow \mathrm{CO}_{2}
\end{gathered}
$$

Accordingly, oxygen excess (OE) was defined as in Equation (5):

$$
E=\frac{\left[O_{2}\right]}{\left[O_{2}\right]_{\text {stoich }}} \times 100 \%
$$

Where $\left[O_{2}\right]$ is the provided initial concentration of $\mathrm{O}_{2}$ from the decomposition of the added hydrogen peroxide according to the decomposition reaction and $\left[\mathrm{O}_{2}\right]_{\text {stoich }}$ is the calculated stoichiometric amount of $\mathrm{O}_{2^{2}}$ according to Equation (4), required to completely oxidize the organic matter measured as TOC, $23200 \mathrm{mg} / \mathrm{L}$ of oxygen for $8700 \mathrm{mg} / \mathrm{L}$ TOC, which is provided by $49300 \mathrm{mg} / \mathrm{L}$ of hydrogen peroxide, $164.3 \mathrm{~g} / \mathrm{L}$ of $30 \mathrm{wt} \%$ hydrogen peroxide solution. Calculated oxidant solution requirement based on this approximation is considerably lower than that resulting from 
the most widely used COD measurement. The exact mass of leachate-oxidant solution to be injected in the reactor is determined based on the specific volume of water at reaction conditions calculated by means of the Peng-Robinson Equation of State (PR-EOS) and the volume of the reactor. PR EOS has been shown to perform as well as the more complicated perturbed hard sphere Van der Waals equations, with a good qualitative picture of all types of phase behavior and reasonable quantitative representation for a variety of systems [27], [28]. The reactor is placed in the oven, previously heated at reaction conditions, and left for a specific reaction time. Once the reaction time is finished, the reactor is removed from the oven and immersed in a cold water bath to stop the reaction. Liquid effluent is collected for TOC and TN analysis. No attempt was made to collect the gaseous phase at this stage of the research.

\subsection{Statistical analysis}

Experimental runs were planned according to a replicated twice $2^{k}$ full factorial design with three factors $(k)$ : temperature $(A)$, reaction time (B) and oxygen excess (C), using TOC and TN as response variables. Low and high levels of each factor $(-1,+1)$ were selected according to preliminary experiments as well as practical considerations regarding reactor construction materials and hydrogen peroxide consumption. Thus, levels of temperature were 400 and $500{ }^{\circ} \mathrm{C}, 15$ and $30 \mathrm{~min}$ reaction time and oxygen excess of 100 and $300 \%$. With four repetitions in the central point $\left(450^{\circ} \mathrm{C}, 22.5 \mathrm{~min}\right.$, and $\left.200 \% \mathrm{OE}\right)$, the full design is comprised of 20 experimental runs, made in randomized order. Statistical analysis of the results was made according to the analysis of variance (ANOVA) on both response variables, as well as the graphical analysis of the significant main effects and interactions plots, by using the statistical software package Minitab.

\section{RESULTS AND DISCUSSION}

The summary of reaction conditions, initial and final TN and TOC concentrations and destruction efficiencies, is shown in Table 1 , in which $\mathrm{T}$ is the reaction temperature and Time is the total reaction time. Runs are identified and shown according to the label in the $2^{k}$ experimental design and the order in which each run was carried out. For example, run 5-bc means it was the 5 run in the experimental design, with factor $(A)$ in the level low, reaction temperature $400^{\circ} \mathrm{C}$, whereas factors $B$ and $C$ are in the level high, reaction time and oxygen excess $30 \mathrm{~min}$ and $300 \%$, respectively. Run 8-(1) means all the factors were in the level low, $400^{\circ} \mathrm{C}, 15 \mathrm{~min}$ and $100 \% \mathrm{OE}$.

For all the treatment conditions in the experimental design, TOC destruction efficiencies were higher than $70 \%$, whereas TN destruction efficiencies were lower, with efficiencies higher than $30 \%$. Maximum destruction efficiency for TOC was $99.5 \%$ at $400^{\circ} \mathrm{C}, 30 \mathrm{~min}$ reaction time and $300 \%$ $\mathrm{OE}$, whereas for $\mathrm{TN}$ was $92.2 \%$ at $500^{\circ} \mathrm{C}, 30$ min and $100 \%$ OE. These results suggest the organic matter in the leachate can be effectively oxidized at $400^{\circ} \mathrm{C}$. However, nitrogen abatement might require a more aggressive treatment at $500{ }^{\circ} \mathrm{C}$. An analysis 
of variance (ANOVA) of the experimental ral conclusion regarding the optimal set of data was carried out in order to elucidate operation conditions can be drawn. ANOVA the joint effect of the factors and its interac- for TOC and TN destruction efficiencies is tions on the response, so that a more gene- discussed next.

Table 1. Summary of reaction conditions, initial and final TOC and TN concentrations and destruction efficiencies

\begin{tabular}{|c|c|c|c|c|c|c|c|c|c|}
\hline $\begin{array}{l}\text { Run- } \\
\text { label }\end{array}$ & $\begin{array}{c}\mathrm{T} \\
\left({ }^{\circ} \mathrm{C}\right)\end{array}$ & $\begin{array}{l}\text { Time } \\
\text { (min) }\end{array}$ & OE (\%) & $\underset{(\mathrm{mg} / \mathrm{L})}{\mathrm{TN}_{\mathrm{i}}}$ & $\underset{(\mathrm{mg} / \mathrm{L})}{\mathrm{TN}_{\mathrm{f}}}$ & $\begin{array}{l}X_{\mathrm{TN}} \\
(\%)\end{array}$ & $\begin{array}{l}\mathrm{TOC}_{\mathrm{i}} \\
(\mathrm{mg} / \mathrm{L})\end{array}$ & $\begin{array}{c}\mathrm{TOC}_{\mathrm{f}} \\
\text { (mg/L) }\end{array}$ & $\begin{array}{l}X_{\text {Tod }} \\
(\%)\end{array}$ \\
\hline $1-a b$ & 500 & 30 & 100 & 2187.5 & 170 & 92.2 & 6797 & 910 & 86.6 \\
\hline 2- 0 & 450 & 22.5 & 200 & 1971.9 & 920 & 53.3 & 6127 & 940 & 84.7 \\
\hline $3-a b c$ & 500 & 30 & 300 & 1794.9 & 420 & 76.6 & 6127 & 940 & 83.2 \\
\hline $4-(1)$ & 400 & 15 & 100 & 2187.5 & 1470 & 32.8 & 6797 & 1970 & 71.0 \\
\hline $5-b c$ & 400 & 30 & 300 & 1794.9 & 560 & 68.8 & 5577 & 200 & 96.4 \\
\hline $6-a b c$ & 500 & 30 & 300 & 1794.9 & 220 & 87.7 & 5577 & 1170 & 79.0 \\
\hline $7-c$ & 400 & 15 & 300 & 1794.9 & 1170 & 34.8 & 5577 & 1980 & 65.0 \\
\hline 8-(1) & 400 & 15 & 100 & 2187.5 & 1360 & 37.8 & 6797 & 1970 & 71.0 \\
\hline $9-a c$ & 500 & 15 & 300 & 1794.9 & 840 & 53.2 & 5577 & 550 & 82.6 \\
\hline $10-a$ & 500 & 15 & 100 & 2187.5 & 1280 & 41.5 & 6797 & 1220 & 83.0 \\
\hline $11-\mathrm{ac}$ & 500 & 15 & 300 & 1794.9 & 660 & 63.2 & 5577 & 970 & 82.6 \\
\hline $12-0$ & 450 & 22.5 & 200 & 1971.9 & 700 & 64.5 & 6127 & 600 & 90.2 \\
\hline $13-0$ & 450 & 22.5 & 200 & 1971.9 & 830 & 57.9 & 6127 & 1470 & 76.0 \\
\hline $14-b$ & 400 & 30 & 100 & 2187.5 & 870 & 60.2 & 6797 & 1210 & 98.2 \\
\hline $15-b c$ & 400 & 30 & 300 & 1794.9 & 380 & 78.8 & 5577 & 30 & 99.5 \\
\hline $16-a b$ & 500 & 30 & 100 & 2187.5 & 460 & 79.0 & 6797 & 1460 & 78.5 \\
\hline 17-C & 400 & 15 & 300 & 1794.9 & 1130 & 37.0 & 5577 & 1960 & 64.9 \\
\hline 18-0 & 450 & 22.5 & 200 & 1971.9 & 530 & 73.1 & 6127 & 1420 & 76.8 \\
\hline $19-b$ & 400 & 30 & 100 & 2187.5 & 540 & 75.3 & 6797 & 550 & 91.9 \\
\hline $20-a$ & 500 & 15 & 100 & 2187.5 & 1190 & 45.6 & 6797 & 750 & 89.0 \\
\hline
\end{tabular}

Source: The authors. 


\subsection{Total organic carbon ANOVA}

According to the TOC normal plot of standardized effects shown in Fig. 2, factor B (Reaction time) and the interaction $A B$ (Temperature and reaction time) have a significant effect on the response. However, factor A (Temperature) and factor $C$ (oxygen excess) did not have a significant effect. Temperature and oxygen have a positive effect on oxidation reactions rates, and SCWO studies are usually carried out in a continuous manner with a few seconds of residence time at temperatures higher than $500^{\circ} \mathrm{C}$ and oxygen excess over $300 \%$ [15], [20]. The lack of a positive effect in both factors could be attributed to the prolonged reaction time considered in this study, which was long enough, even in the level low, for the oxidation reaction to proceed almost to completion. On the other hand, as expected in any reaction, the interaction between temperature and time means working at higher temperature results in a shorter reaction time. The nature of the interaction for this study is discussed next.

The model had a regression coefficient $\mathrm{R}^{2}=88.39 \%$. Since $A, C, B C, A C$ and $A B C$ terms are insignificant; the design was reanalyzed dropping these terms from the model. The normal probability plot of the residuals and residuals versus. fitted values or constant variance plot for the re-analyzed design are shown in Figs. 3 and 4.

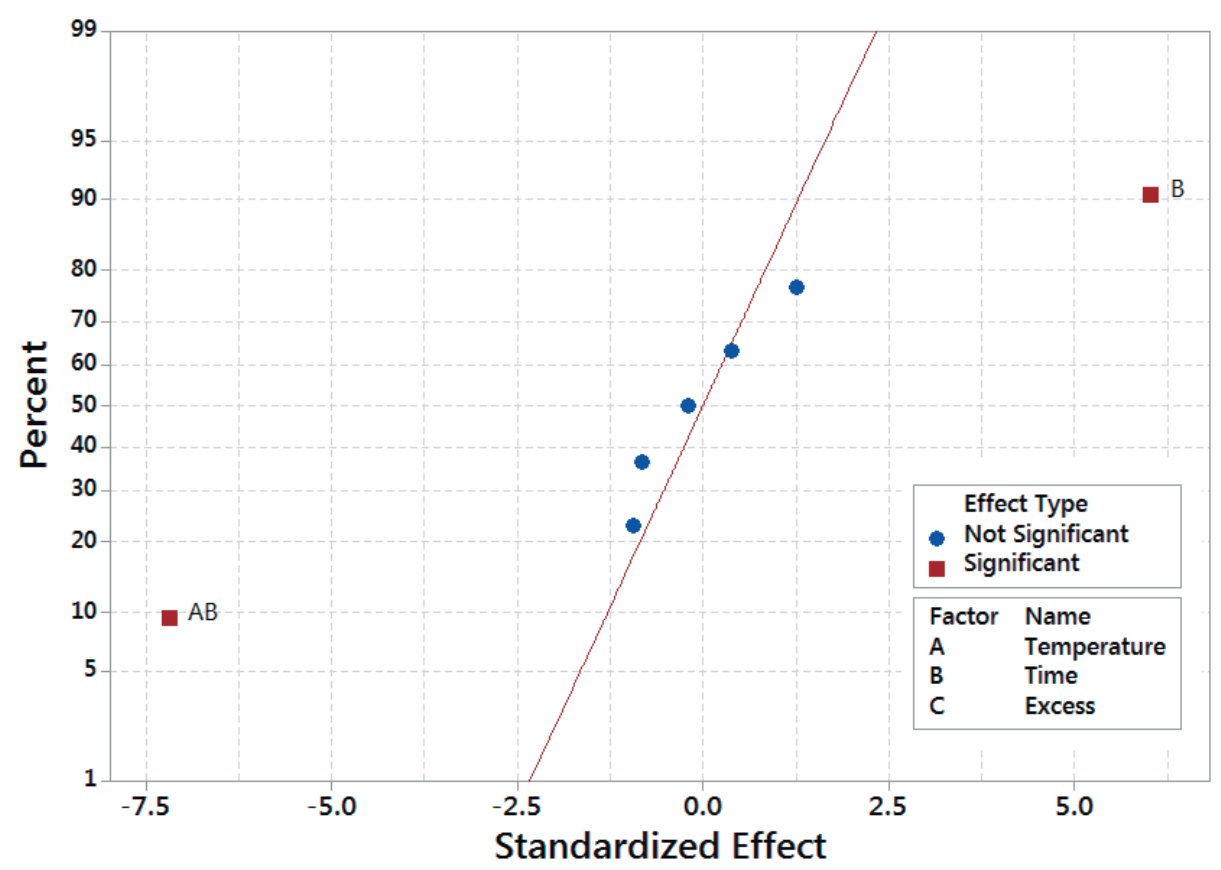

Fig. 2. TOC normal plot of standardized effects $(a=0.05)$

Source: The authors. 


\section{Ciencia e Ingeniería Neogranadina}

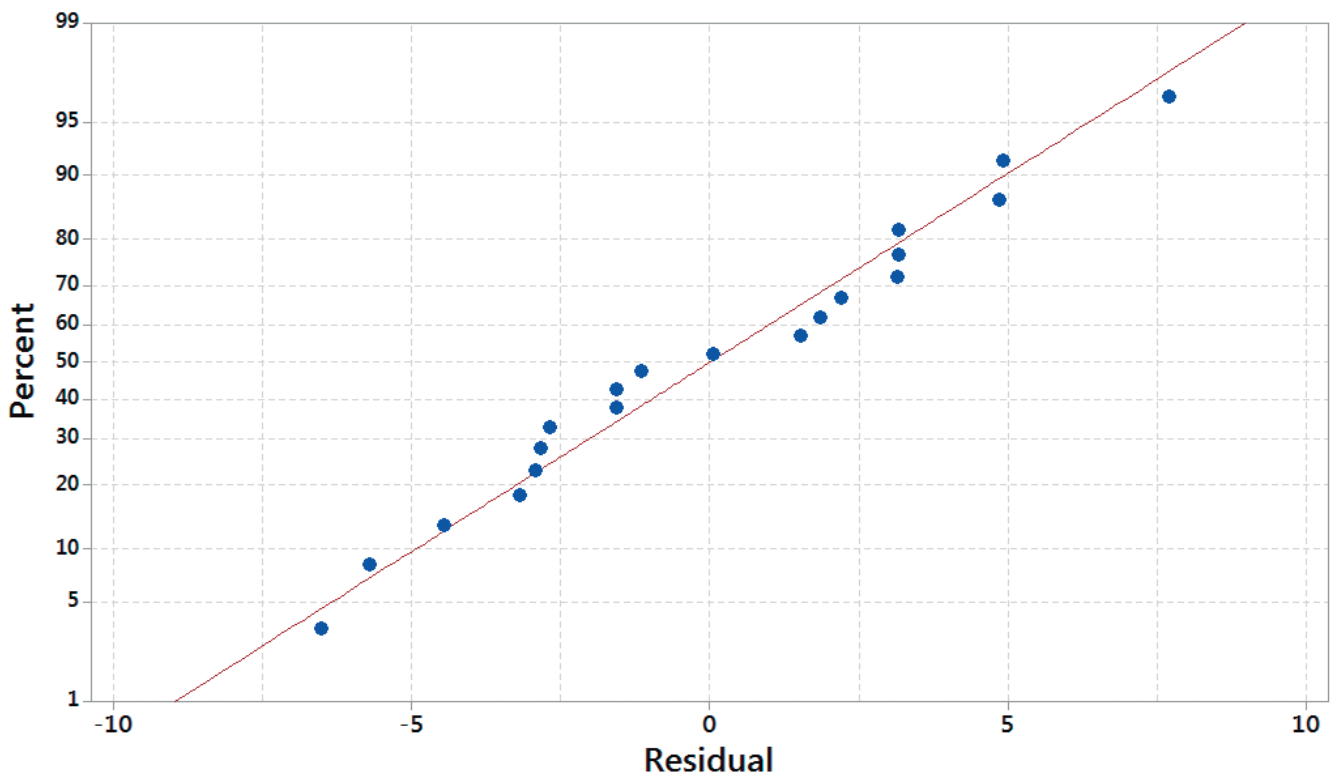

Fig. 3. Normal probability plot of the residuals Source: The authors.

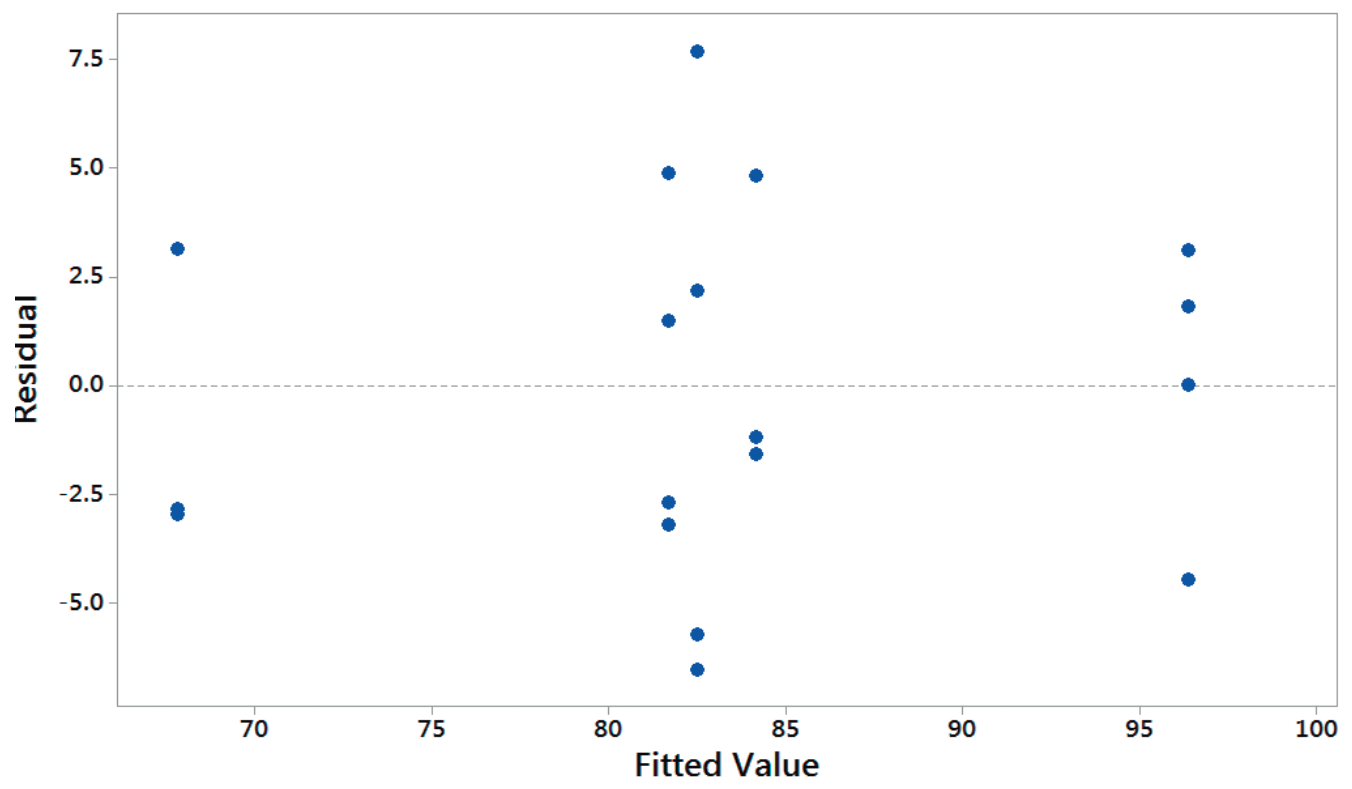

Fig. 4. TOC constant variance plot of the residuals Source: The authors. 
As can be observed in Fig. 3, the normal probability plot of the residuals resembles a straight line; therefore the error distribution is normal. In a similar way, Fig. 4 shows a random patter of the residuals on both si- des of 0 , without any recognizable patterns. Therefore, the model is correct and the assumptions were satisfied. ANOVA for the re-analyzed model is summarized in Table 2 and resulting model is given in Equation (6).

Table 2. ANOVA for TOC destruction efficiency

\begin{tabular}{|l|l|l|l|l|l|}
\hline \multicolumn{1}{|c|}{ Source of Variation } & $\begin{array}{c}\text { Degrees of } \\
\text { freedom }\end{array}$ & $\begin{array}{c}\text { Sum of } \\
\text { squares }\end{array}$ & \multicolumn{1}{|c|}{$\begin{array}{c}\text { Mean } \\
\text { square }\end{array}$} & F。 & P-value \\
\hline Model & 3 & 1642.3 & 547.4 & 31.0 & 0.000 \\
\hline Linear & 2 & 681.3 & 340.7 & 19.3 & 0.001 \\
\hline Temperature & 1 & 2.7 & 2.7 & 0.2 & 0.709 \\
\hline Time & 1 & 678.6 & 678.6 & 38.5 & 0.000 \\
\hline 2-Way Interactions & 1 & 961.0 & 961.0 & 54.5 & 0.000 \\
\hline Temperature*Time & 1 & 961.0 & 961.0 & 54.5 & 0.000 \\
\hline Error & 16 & 282.2 & 17.6 & & \\
\hline Lack-of-Fit & 5 & 60.4 & 12.1 & 0.6 & 0.778 \\
\hline Pure Error & 11 & 221.8 & 20.2 & & \\
\hline Total & 19 & 1924.5 & & & \\
\hline
\end{tabular}

Source: The authors.

TOC $=-150.0+0.4733^{\star}$ Temperature $+10.17 \star$ Time $-0.02067 \star$ Temperature*Time

The standard deviation was 4.19959. According to the P-values in the ANOVA for TOC destruction efficiency in Table 2, the model has a P-value of 0.000 , whereas lack of fit was not significant, which means the model fits well the data. In a similar way, the main effects of reaction time (B) and the interaction $A B$ of temperature and reaction time are highly significant, with P-values $<0.01$.
According to Montgomery [29], the main effects do not have much meaning when there are involved significant interactions. While the positive effect estimated for B factor suggest working at the high level of the reaction time to increase the TOC destruction efficiency, $A B$ interaction might indicate the opposite trend. $A B$ interaction plot is shown in Fig. 5. 


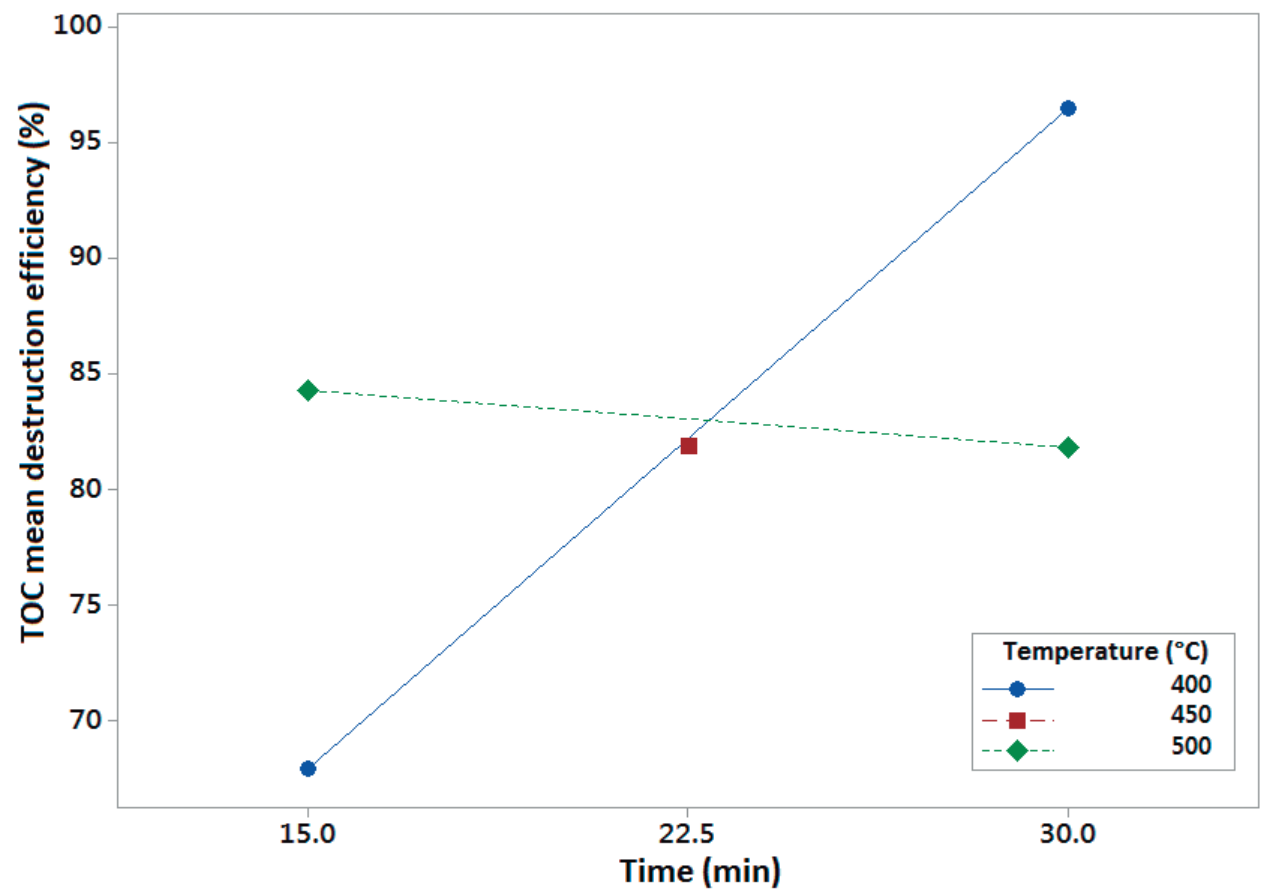

Fig. 5. Temperature $\left({ }^{\circ} \mathrm{C}\right)$ - time $(\mathrm{min})(\mathrm{AB})$ interaction

Source: The authors.

Fig. 5 shows that the effect of time is significant when working at $400^{\circ} \mathrm{C}$ and negligible when working at $500^{\circ} \mathrm{C}$. The higher reaction temperature speeds up the reaction and as a result, the TOC mean destruction efficiencies are similar at 15 and 30 minutes, as was previously discussed. However, TOC mean destruction efficiencies are higher when working at $400^{\circ} \mathrm{C}$ and 30 min reaction time. Usually, SCWO experimental studies report a positive effect of temperature when working in a continuous unit set up and with residence times of a few seconds [15], [30]. The heating time of the substance to oxidize and the oxidant agent pumped separately, is not accounted for as part of the total reaction time and could be even longer than the residence time in the reactor. From Fig. 5 it can be concluded that the optimal operation conditions for TOC destruction are 400 ${ }^{\circ} \mathrm{C}, 30$ min reaction time and $100 \%$ oxygen excess since this factor was not significant. However, factors effect on TN destruction could be different and suggest a different set of operation conditions. TN ANOVA is discussed next.

\subsection{Total nitrogen ANOVA}

ANOVA for TN destruction efficiency is shown in Table 3, and TN normal plot of standardized effects is presented in Fig. 6. Data standard deviation was 7.18584. The model in Equation (7) had a P-value of 0.000, 
and an $\mathrm{R}^{2}$ value of $90.23 \%$, lack of fit was not significant, which means the model fits well the data. Main factors A and B, temperature and time, have a significant effect on nitrogen abatement, with P-values for temperature and time of 0.001 and 0.000 , respectively. Oxidant excess did not have a positive effect, which can be attributed again to the prolonged reaction time. Differently, from what was observed for TOC destruction, there are no significant interactions for TN. Accordingly, the design was re-analyzed dropping the ter$m s C, A C, B C, A B$ and $A B C$ from the analysis. The results are shown in Figs. 7 and 8. Normal probability plot resembles a straight line, and residuals show a random pattern around 0 ; therefore, there is no reason to suspect any problems with the validity of the conclusion. TN temperature and time main effects plot is shown in Fig. 9.

Table 3. ANOVA for TN destruction efficiency

\begin{tabular}{|l|l|l|l|l|l|}
\hline \multicolumn{1}{|c|}{ Source of Variation } & \multicolumn{1}{|c|}{$\begin{array}{c}\text { Degrees of } \\
\text { freedom }\end{array}$} & $\begin{array}{c}\text { Sum of } \\
\text { squares }\end{array}$ & $\begin{array}{c}\text { Mean } \\
\text { square }\end{array}$ & F。 & P-value \\
\hline Model & 2 & 5453.0 & 2726.49 & 52.20 & 0.000 \\
\hline Linear & 2 & 5453.0 & 2726.49 & 52.20 & 0.000 \\
\hline Temperature & 1 & 805.1 & 805.14 & 15.42 & 0.001 \\
\hline Time & 1 & 4647.8 & 4647.83 & 88.99 & 0.000 \\
\hline Error & 17 & 887.9 & 52.23 & & \\
\hline Lack-of-Fit & 6 & 280.0 & 46.67 & 0.84 & 0.562 \\
\hline Pure Error & 11 & 607.9 & 55.26 & & \\
\hline Total & 19 & 6340.8 & & & \\
\hline
\end{tabular}

$\mathrm{TN}=-54.3+0.1419 *$ Temperature $+2.272 *$ Time 


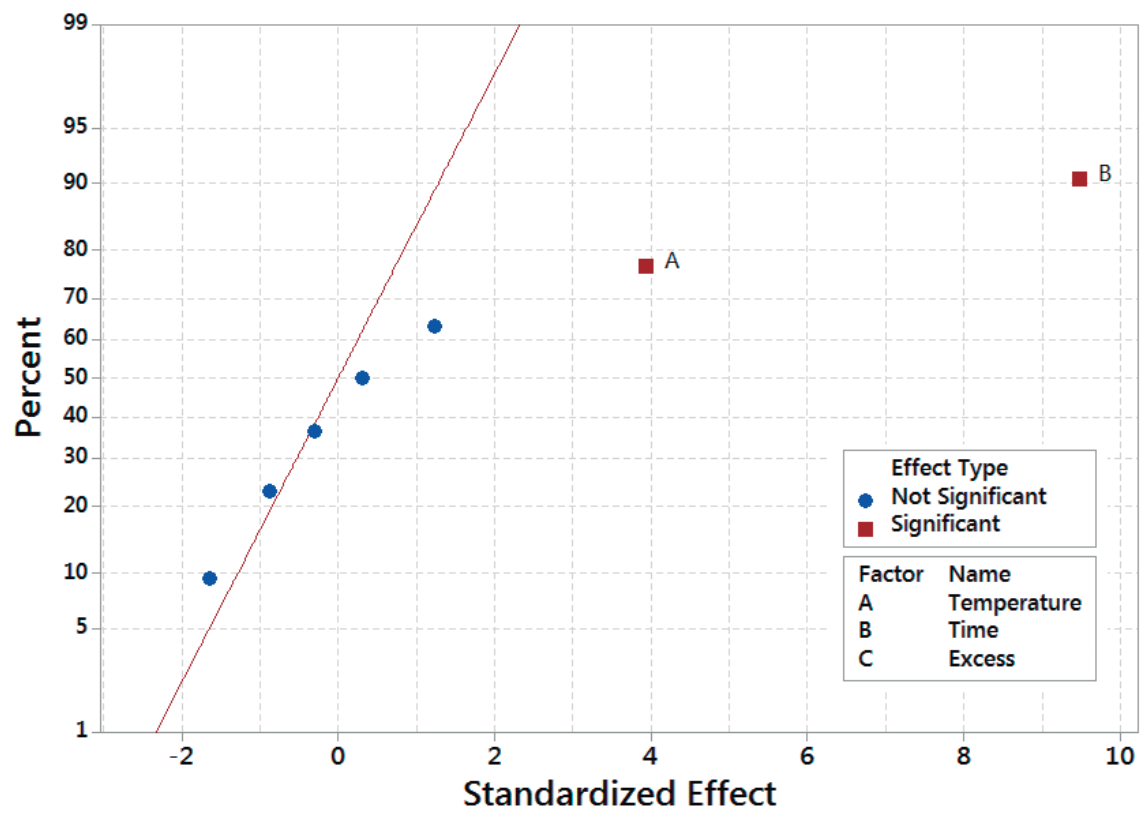

Fig. 6. TN normal plot of standardized effects $(a=0.05)$

Source: The authors.

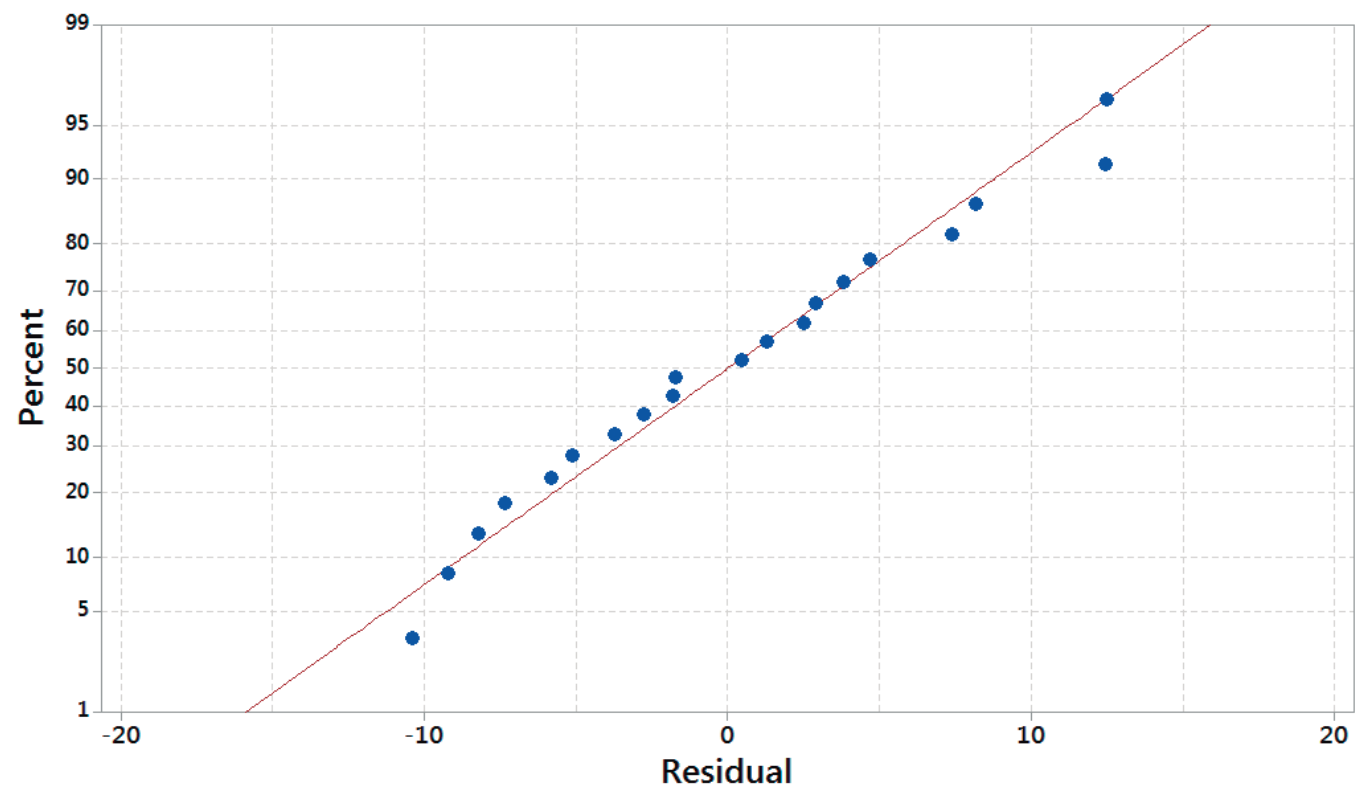

Fig. 7. TN normal probability plot of the residuals

Source: The authors. 


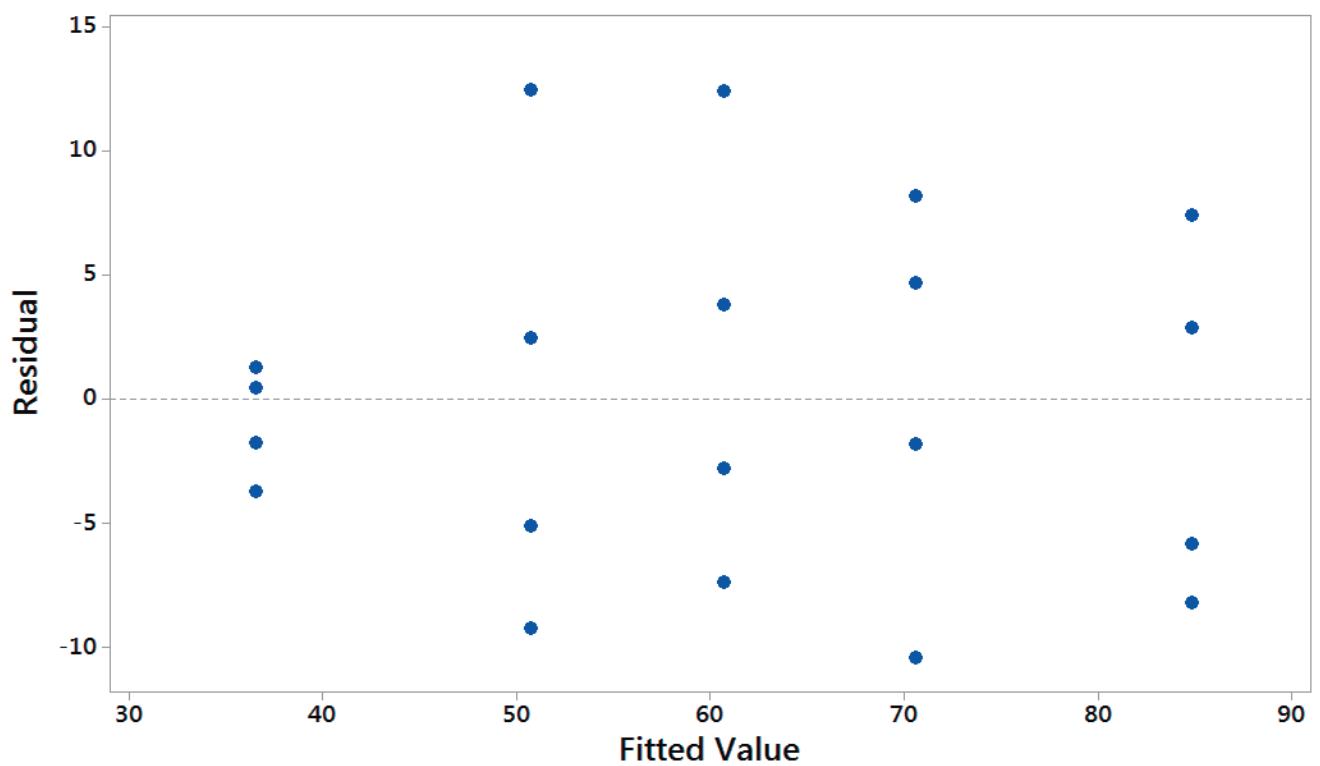

Fig. 8. TN constant variance plot of the residuals

Source: The authors.

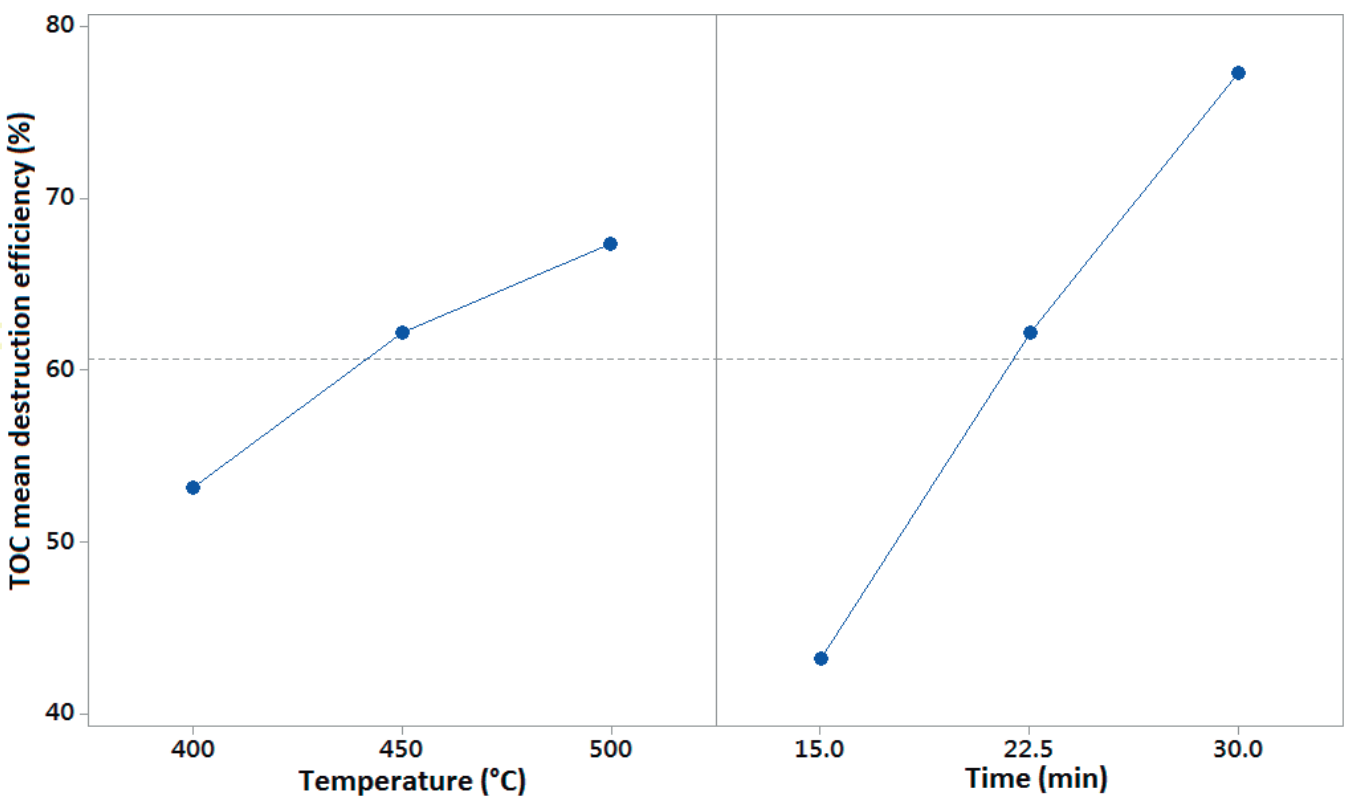

Fig. 9. TN temperature $\left({ }^{\circ} \mathrm{C}\right)$ and time $(\mathrm{min})$ main effects plot Source: The authors. 
Fig. 9 shows the positive effects of temperature and time, which suggest the optimal operation conditions for achieving a high TN destruction efficiency are $500{ }^{\circ} \mathrm{C}, 30 \mathrm{~min}$ reaction time and $100 \%$ oxygen excess. Although temperature effect was found insignificant for TOC destruction when working at residence times longer than $15 \mathrm{~min}$, ammonia-nitrogen $\left(\mathrm{NH}_{3}-\mathrm{N}\right)$, formed as a stable intermediate compound in the oxidation of nitrogen-containing components, is a weII-known recalcitrant compound and usually requires temperatures higher than $600{ }^{\circ} \mathrm{C}$ in the SCWO process [6], [31]-[33]. In fact, it has been suggested the ammonia oxidation to nitrogen or nitrous oxide is the rate limiting step in the global oxidation [7]. At $400^{\circ} \mathrm{C}$, $30 \mathrm{~min}$ and $\mathrm{OE}$ of $100 \%$, optimal operation conditions for TOC destruction, average TN destruction of runs 14 and 19 is $68 \%$, which might be insufficient to meet the most stringent TN discharge limits. However, this result is much better than the $46.9 \%$ ammonia conversion reported by Wang et al. [23] in the SCWO of leachate at $400^{\circ} \mathrm{C}, \mathrm{OE}$ of $350 \%$ and $300 \mathrm{~s}$ reaction time, with a heating velocity of $4.07^{\circ} \mathrm{C} / \mathrm{min}$ in the absence of the oxidant.

The difference could be attributed to the experimental procedure followed in this work, in which the leachate and oxidant were mixed and heated up to reaction conditions and left for a particular time. In this aspect, hydrogen peroxide rapidly decomposes with temperature, producing reactive $\mathrm{OH}$ free radicals [26], which could promote fast organic matter oxidation reactions. Heating up separately could cause pyrolysis of the organic compounds [34], [35] as well as the thorough decomposition of peroxide to oxygen, which is a less reactive oxidant agent. Temperature-time contour plots for TOC and TN destruction efficiencies, generated by the statistical software Minitab from data quadratic regression models in the studied experimental region, are shown in Fig. 10. As it was shown in TOC ANOVA, the temperature-time significant interaction causes the TOC destruction efficiency contour plots to curve when temperature goes from low $\left(400^{\circ} \mathrm{C}\right)$ to high $\left(500^{\circ} \mathrm{C}\right)$, whereas TN contour plots are straight due to the absence of significant interactions and TN destruction efficiency increases with the temperature and time. Although high TN destruction efficiency can be obtained at $500^{\circ} \mathrm{C}$, as shown in $\mathrm{TN}$ contour plots and also suggested by other works [23], Fig. 9 indicates that a reaction time longer than 30 min could increase TN destruction efficiency. Therefore, not only high TOC but also TN destruction efficiency could be obtained working at $400^{\circ} \mathrm{C}, \mathrm{OE}$ of $100 \%$ and reaction times longer than $30 \mathrm{mi}-$ nutes. From a scale-up point of view, a reaction temperature of $400^{\circ} \mathrm{C}$ is more desirable than $500^{\circ} \mathrm{C}$ due to increased cost of equipment construction materials and also the higher energy consumption expected when working at $500^{\circ} \mathrm{C}$. Even though the results were obtained in a batch reactor, the implemented experimental procedure of mixing the leachate and oxidant and heating up to reaction conditions would be similar to the operation of a continuous unit in which the leachate-oxidant mixture is pumped through preheaters up to the reaction temperature and kept constant for a residence time similar to those found in this study. 

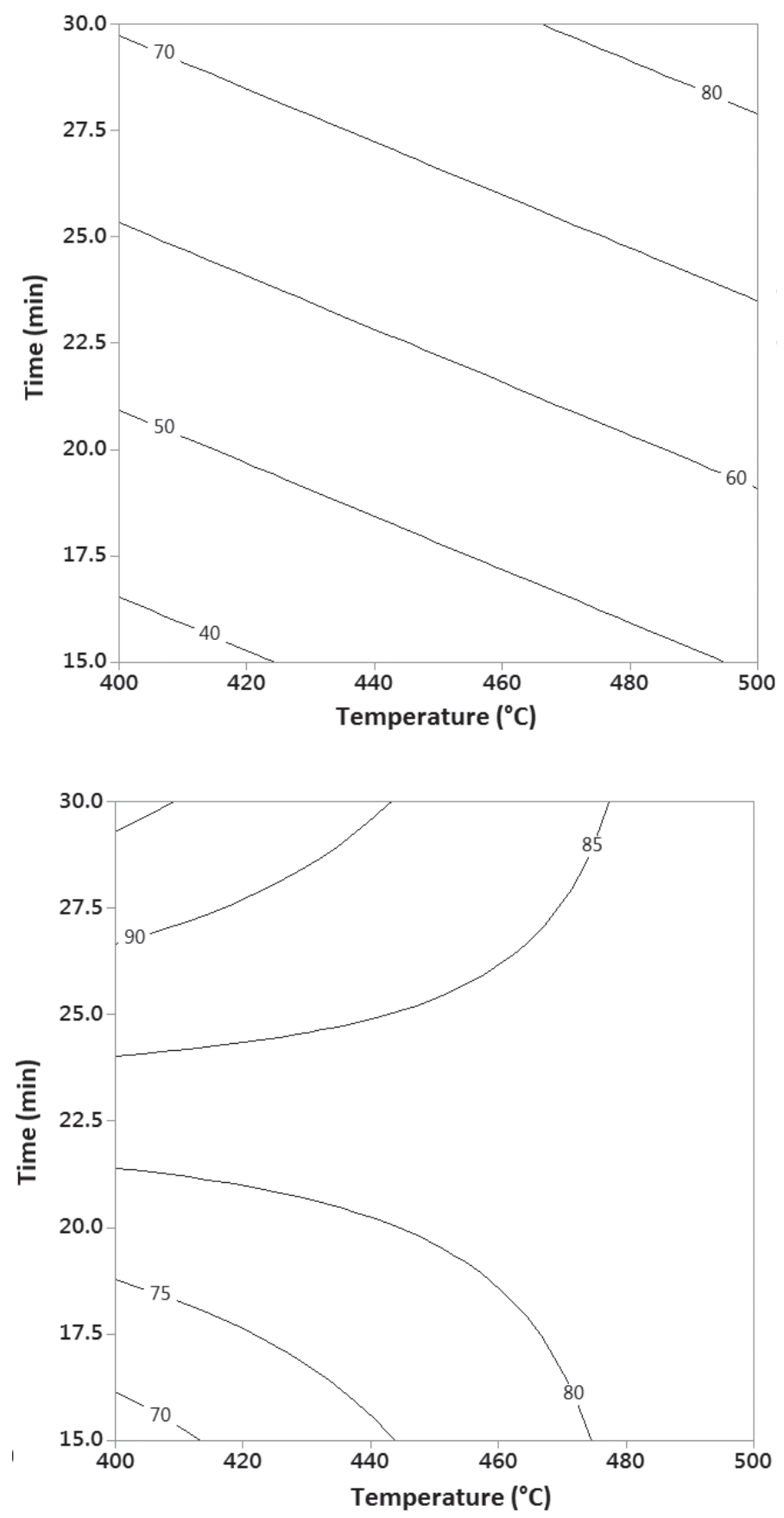

Fig. 10. Temperature $\left({ }^{\circ} \mathrm{C}\right)$ - time (min) Contour plots for TOC (top) and TN (down) destruction efficiency (\%)

Source: The authors. 


\section{CONCLUSIONS}

This work reports the SCWO of landfill leachate in a batch reactor system in which the joint effect of temperature, time and oxygen excess were assessed using a factorial experimental design. ANOVA for TOC and TN destruction efficiency showed the temperature-time interaction was significant for TOC destruction efficiency and the interaction plot showed the optimal operation conditions for TOC destruction were $400^{\circ} \mathrm{C}, 30 \mathrm{~min}$ and $100 \%$ OE. Temperature and time factors were significant for TN destruction efficiency, which were higher than those reported by other works at similar reaction conditions: main effect plots showed the optimal operation conditions were $500^{\circ} \mathrm{C}, 30 \mathrm{~min}$ and $100 \%$ OE. Although the higher temperature is required for $\mathrm{TN}$ destruction, contour plots showed an even longer reaction time could increase $\mathrm{TN}$ destruction efficiencies while keeping the reaction temperature at $400^{\circ} \mathrm{C}$, a more desirable reaction temperature from a scale-up point of view.

Finally, it is important to strengthen the development of this type of research, mainly because in the past some knowledge limitations have been found and one of the biggest gaps is the easy way methodology to carry out a risk assessment, specifically for landfill leachate [36]. Likewise in different countries, there is some evidence that shows the research on sources contaminated with leachate was useful for enforcing the environmental regulations and improving the environmental quality [37].

\section{ACKNOWLEDGMENTS}

The authors wish to thank the Colombian Institute of Science and Technology (COLCIENCIAS) for a young researcher grand awarded to engineer Paola Marulanda to carry out research at Universidad de La Salle in Bogotá for one year.

\section{REFERENCES}

[1] P. Ghosh, I. S. Thakur and A. Kaushik, "Bioassays for toxicological risk assessment of landfill leachate: A review," Ecotoxicol. Environ. Saf., vol.141, pp. 259-270, Jan. 2017. https://doi. org/10.1016/j.ecoenv.2017.03.023

[2] T. A. Kurniawan, W. H. Lo and G. Y. S. Chan, "Physico-chemical treatments for removal of recalcitrant contaminants from landfill leachate," Jour. Hazard. Mater., vol. 129, no. 1-3, pp. 80100, 2006. https://doi.org/10.1016/j. jhazmat.2005.08.010

[3] Y. N. Vodyanitskii, "Biochemical processes in soil and groundwater contaminated by leachates from municipal landfills (Mini Review)," Ann. Agrar. Sci., vol.14, no. 3, pp. 1512-1887, 2016. https://doi. org/10.1016/j.aasci.2016.07.009

[4] N. B. Yenigül, A. M. M. Elfeki, J. C. Gehrels, C. van den Akker, A. T. Hensbergen and F. M. Dekking, "Reliability assessment of groundwater monitoring networks at landfill sites," Jour. Hydrol., vol. 308, no. 1-4, pp. 1-17, 2005. https:// doi.org/10.1016/j.jhydrol.2004.10.017

[5] S. Renou, J. G. Givaudan, S. Poulain, F. Dirassouyan and P. Moulin, "Landfill 
leachate treatment: Review and opportunity," Jour. Hazard. Mater., vol. 150, no. 3, pp. 468-493, 2008. https://doi. org/10.1016/j.jhazmat.2007.09.077

[6] J. M. Ploeger, A. C. Madlinger and J. W. Tester, "Revised Global Kinetic Measurements of Ammonia Oxidation in Supercritical Water," Ind. Eng. Chem. Res., vol. 45, no. 20, pp. 6842-6845, 2006. https://doi.org/10.1021/ie0605276

[7] M. D. Bermejo, F. Cantero and M. J. Cocero, "Supercritical water oxidation of feeds with high ammonia concentrations Pilot plant experimental results and modeling," Chem. Eng. Jour., vol.137, no. 3, pp. 542549, 2008. https://doi.org/10.1016/j. cej.2007.05.010

[8] L. Labiadh, A. Fernandes, L. Ciríaco, M. J. Pacheco et al., "Electrochemical treatment of concentrate from reverse osmosis of sanitary landfill leachate," $\mathrm{J}$. Environ. Manage., vol. 181, pp. 515-521, Oct. 2016. https://doi.org/10.1016/j. jenvman.2016.06.069

[9] J. Xu, Y. Long, D. Shen, H. Feng and T. Chen, "Optimization of Fenton treatment process for degradation of refractory organics in pre-coagulated leachate membrane concentrates," Jour. Hazard. Mater., vol. 323, pp. 674680, 2017. https://doi.org/10.1016/j. jhazmat.2016.10.031

[10] S. Renou, S. Poulain, J. G. Givaudan and P. Moulin, "Treatment process adapted to stabilized leachates: Lime precipitation-prefiltration-reverse osmosis," Jour. Memb. Sci., vol. 313, no. 1-2, pp.
9-22, 2008. https://doi.org/10.1016/j. memsci.2007.11.023

[11] J. R. Portela, E. Nebot and E. Mart, "Hydrothermal oxidation: Application to the treatment of different cutting fluid wastes," Jour. Hazard. Mater., vol. 144, no. 3, pp. 639-644, 2007. https://doi. org/10.1016/j.jhazmat.2007.01.088

[12] M. J. Cocero, E. Alonso and M. T. Sanz, "Supercritical water oxidation process under energetically self-sufficient operation,". Jour. Supercrit. Fluids, vol. 24 , no. 1, pp. 37-46, 2002. https://doi. org/10.1016/s0896-8446(02)00011-6

[13] Y. García-Rodríguez, F. Mato, A. Martín, M. D. Bermejo and M. J. Cocero, "Energy recovery from effluents of supercritical water oxidation reactors," Jour. Supercrit. Fluids, vol. 104, pp. 1-9, Sep. 2015. https:// doi.org/10.1016/j.supflu.2015.05.014

[14] V. F. Marulanda, "Biodiesel production by supercritical methanol transesterification: Process simulation and potential environmental impact assessment," Jour. Clean. Prod., vol. 33, pp. 109-116, 2015. https://doi.org/10.1016/j.jclepro.2012.04.022

[15] V. Marulanda and G. Bolaños, "Supercritical water oxidation of a heavily PCB-contaminated mineral transformer oil: Laboratory-scale data and economic assessment," Jour. Supercrit. Fluids, vol. 54, pp. 258-265, Aug. 2010. https://doi. org/10.1016/j.supflu.2010.04.008

[16] J. M. N. van Kasteren and a. P. Nisworo, "A process model to estimate the cost of industrial scale biodiesel production from waste cooking oil by su- 
percritical transesterification," Resour. Conserv. Recycl., vol. 50, no. 4, pp. 442458, 2007. https://doi.org/10.1016/j. resconrec.2006.07.005

[17] B. Cui, F. Cui, G. Jing, S. Xu et al., “Oxidation of oily sludge in supercritical water," Jour. Hazard. Mater., vol. 165, no. 1-3, pp. 511-517, 2009. https://doi. org/10.1016/j.jhazmat.2008.10.008

[18] M. Akg and O. Onur, "Treatment of textile wastewater by SCWO in a tube reactor," Jour. Supercrit. Fluids, vol. 43, no.1, pp. 106-111, 2007.

[19] X. Du, R. Zhang, Z. Gan and J. Bi, "Treatment of high strength coking wastewater by supercritical water oxidation," Fuel, vol. 104, pp. 77-82, Feb. 2013. https:// doi.org/10.1016/j.fuel.2010.09.018

[20] B. Veriansyah, T. Park, J. Lim and Y. Lee, "Supercritical water oxidation of wastewater from LCD manufacturing process: kinetic and formation of chromium oxide nanoparticles," Jour. Supercrit. Fluids, vol. 34, no. 1, pp. 5161, 2005. https://doi.org/10.1016/j. supflu.2004.10.001

[21] P. A. Marrone, "Supercritical water oxidation. Current status of full-scale commercial activity for waste destruction," Jour. Supercrit. Fluids, vol. 79, pp. 283-288, Jul. 2013. https:// doi.org/10.1016/j.supflu.2012.12.020

[22] W. Gong and X. Duan, "Degradation of landfill leachate using transpiring-wall supercritical water oxidation (SCWO) reactor," Waste Manag., vol. 30, no. 11, pp. 2103-2107, 2010. https://doi. org/10.1016/j.wasman.2010.04.028
[23] S. Wang, Y. Guo, C. Chen, J. Zhang et al., "Supercritical water oxidation of landfiII leachate," Waste Manag., vol. 31, no. 9-10, pp. 2027-2035, 2011. https://doi. org/10.1016/j.wasman.2011.05.006

[24] D. Zou, Y. Chi, C. Fu, J. Dong, "Co-destruction of organic pollutants in municipal solid waste leachate and dioxins in fly ash under supercritical water using $\mathrm{H}_{2} \mathrm{O}_{2}$ as oxidant," Jour. Hazard. Mater., vol. 248-249, pp. 177184, 2013. https://doi.org/10.1016/j. jhazmat.2013.01.005

[25] K. Hatakeda, Y. Ikushima, O. Sato, T. Aizawa and N. Saito, "Supercritical water oxidation of polychlorinated biphenyls using hydrogen peroxide," vol. 54 , no. 15-16, pp. 3079-3084, 1999. https://doi. org/10.1016/s0009-2509(98)00392-3

[26] E. Croiset, S. F. Rice and R. G. Hanush, "Hydrogen peroxide decomposition in supercritical water," Am. Inst. Chem. Eng., vol. 43, no. 9, pp. 2343-2352, 1997. https://doi.org/10.1002/aic.690430919

[27] M. Mukhopadhyay. Natural Extracts Using Supercritical Carbon Dioxide. Florida, USA: CRC Press, 2000. https:// doi.org/10.1201/9781420041699

[28] J. L. Dinaro, P. A. Marrone, S. F. Rice, P. A. Webley, "Critical review of kinetic data for the oxidation of methanol in supercritical water," Jour. Supercrit. Fluids, vol. 34, no. 3, pp. 249-286, 2005. https:// doi.org/10.1016/j.supflu.2003.12.018

[29] D. C. Montgomery. Design and Analysis of Experiments ( $8^{\text {th }}$. Ed.). Nueva York: John Wiley \& Sons, 2012. 
[30] B. Veriansyah, J. Kim and J. Lee, “Destruction of chemical agent simulants in a supercritical water oxidation bench-scale reactor," Jour. Hazard. Mater., vol. 147, no. 1-2, pp. 13-19, 2007. https://doi.org/10.1016/j.jhazmat.2006.12.040

[31] R. Killilea, K. C. Swallow and G. T. Hong, "TheFate of Nitrogen in Supercritical-Water Oxidation," Jour. Supercrit. Fluids, vol. 5, no. 1, pp. 72-78, 1992. https://doi. org/10.1016/0896-8446(92)90044-k

[32] G. Knothe, A. C. Matheaus and T. W. Ryan, "Cetane numbers of branched and straight-chain fatty esters determined in an ignition quality tester," Fuel, vol. 82, no. 8, pp. 971-975, 2003. https://doi.org/10.1016/s00162361(02)00382-4

[33] K. M. Benjamin and P. E. Savage, "Supercritical Water Oxidation of Methylamine," Ind. Eng. Chem. Res., vol. 44, no. 14, pp. 5318-5324, 2005. https://doi. org/10.1021/ie0491793

[34] S. Yesodharan, "Supercritical water oxidation: An environmentally safe method for the disposal of organic wastes," Current Science, vol. 82, no. 9, pp. 1112-1122, 2002.

[35] Z. Fang, S. K. Xu, R. L. Smith Jr., K. Arai and J. A. Kozinski, "Destruction of deca-chlorobiphenyl in supercritical water under oxidizing conditions with and without $\mathrm{Na}_{2} \mathrm{CO}_{3}$," Jour. Supercrit. Fluids, vol. 33, no. 3, pp. 247-258, 2005. https:// doi.org/10.1016/j.supflu.2004.08.010

[36] T. E. Butt, E. Lockley and K. O. K. Oduyemi, "Risk assessment of landfill disposal sites - State of the art," Waste Manag., vol. 28, no. 6, pp. 952-964, 2008. https://doi.org/10.1016/j.wasman.2007.05.012

[37] J. A. Reyes-López, J. Ramírez-Hernández, O. Lázaro-Mancilla, C. Carreón-Diazconti and M. M. L. Garrido, "Assessment of groundwater contamination by landfill leachate: $A$ case in México," Waste Manag., vol. 28, no. 1, pp. 33-39, 2008. https://doi.org/10.1016/j. wasman.2008.03.024 